\title{
MODERN ORAL ANTICOAGULANT TREATMENT IN PATIENTS WITH ATRIAL FIBRILLATION AND HEART FAILURE: INSIGHTS FROM THE CLINICAL PRACTICE
}

\author{
OTILIA ANCA ȚICA ${ }^{1,2 \#}$, OVIDIU ȚICA ${ }^{2,3 * *}$, LIANA ANTAL $^{2 \#}$, ADRIAN HATOS ${ }^{4 \#}$, MIRCEA \\ IOACHIM POPESCU ${ }^{1,2 \#}$, ANCA PANTEA STOIAN ${ }^{5 \#}$, OVIDIU GABRIEL BRATU ${ }^{5,6 \#}$, MIHNEA- \\ ALEXANDRU GĂMAN $^{5 \#}$, SILVIU MIREL PIȚURU ${ }^{5 \#}$, CAMELIA CRISTINA DIACONU ${ }^{5,7 \#}$ \\ ${ }^{1}$ Emergency County Clinical Hospital of Oradea, Cardiology Clinic, Gheorghe Doja Street, no. 65, Oradea, Romania \\ ${ }^{2}$ Faculty of Medicine and Pharmacy, University of Oradea, 1st of December Square, no 10, Oradea, Romania \\ ${ }^{3}$ Emergency County Clinical Hospital of Oradea, Pathology Department, Gheorghe Doja Street, no. 65, Oradea, Romania \\ ${ }^{4}$ Faculty of Sociological Sciences, University of Oradea, Romanian Army Street no 5, Oradea, Romania \\ ${ }^{5}$ University of Medicine and Pharmacy "Carol Davila", Bucharest, Romania \\ ${ }^{6}$ Emergency University Central Military Hospital, Bucharest, Romania \\ ${ }^{7}$ Clinical Emergency Hospital of Bucharest, Internal Medicine Clinic, Bucharest, Romania
}

*corresponding author: ovidiu.tica@gmail.com

\#All authors had equal contribution

\begin{abstract}
Atrial fibrillation (AF) and heart failure (HF) are some of the most common cardiovascular pathologies of our century. These two pathologies can frequently coexist, raising particular diagnostic and therapeutic problems. Patients with AF and HF have a high thromboembolic risk, which justifies the indication of long-term anticoagulant therapy. Vitamin $\mathrm{K}$ antagonists (acenocoumarol) have long been the only oral therapeutic option for the prevention of embolic events in this category of patients. However, the great variability of their anticoagulant effect, with the necessity of monthly monitoring of the coagulation parameters, led to the search of newer therapeutic options, with a more predictable effect and reduced side effects. Modern therapeutic alternatives, such as non-vitamin $\mathrm{K}$ oral agents (dabigatran, rivaroxaban, apixaban, edoxaban), have appeared. In this study, we aimed to evaluate the role of oral anticoagulant therapy, especially non-vitamin K, in managing patients with both pathologies.
\end{abstract}

\section{Rezumat}

Fibrilația atrială (FA) și insuficiența cardiacă (IC) reprezintă unele dintre cele mai frecvent întâlnite patologii cardiovasculare ale secolului nostru. Cele două patologii pot frecvent coexista, ridicând probleme deosebite de diagnostic și tratament. Pacienții cu FA și IC au un risc crescut tromboembolic, care justifică indicația de tratament anticoagulant pe termen lung. Antagoniştii de vitamina K (acenocumarolul) au reprezentat multă vreme singura opțiune terapeutică orală pentru prevenția evenimentelor embolice la această categorie de pacienți. Variabilitatea crescută a efectului lor anticoagulant, care impune necesitatea monitorizării lunare a acestuia, a condus la căutarea unor noi clase de medicamente anticoagulante, cu un efect terapeutic mai previzibil şi efecte secundare mai reduse. Au apărut astfel alternative terapeutice moderne, ca anticoagulantele orale non-vitamina $\mathrm{K}$ (dabigatran, rivaroxaban, apixaban, edoxaban).

Keywords: atrial fibrillation, heart failure, new oral anticoagulants, non-vitamin K anticoagulants

\section{Introduction}

Atrial fibrillation (AF) and heart failure (HF) are two major cardiac pathologies, with increasing prevalence over the past decades $[4,16]$ and high mortality [10].

These two pathologies can frequently coexist [26], raising particular diagnostic and therapeutic problems. Patients with AF and HF have a high thromboembolic risk, which justifies the indication of longterm anticoagulant therapy. Substantial progress was made during the last years in stroke prevention for $\mathrm{AF}$, this being reflected in the recent international guidelines recommendations. So far, this is the main therapeutic target in these patients [3, 12]. However, only a small amount of data is available and there are only a few publications [9] and recommendations on the anticoagulant treatment in patients with AF in HF.

Acenocoumarol, a vitamin $\mathrm{K}$ antagonist (VKA), has long been the only oral anticoagulant option in preventing embolic events. Modern therapeutic alternatives, non-vitamin $\mathrm{K}$ oral anticoagulants (dabigatran, rivaroxaban, apixaban, edoxaban) have shown some advantages over "classical" anticoagulant medication $[11,18,19,25]$. 
New oral anticoagulants (NOACs) represent one of the most important drug discoveries of our century [6]. These drugs are the outcome of understanding the treatment of pathological coagulation. Unlike VKA, which tackle the coagulation as a whole, NOACs target the appropriate molecules of the coagulation mechanism [8]. Understanding the pharmacological implication of the molecule [15] and the physiological substrate of their specific target represent the cornerstone of a superior drug. Unlike VKA, NOACs have a predictable therapeutic response [20], rapid onset of action, few drug interactions and no requirement for regular coagulation monitoring.

One of the most feared complications when using anticoagulants is the risk of haemorrhages [21]. In most studies, NOACs proved to be superior to VKA for prevention of stroke and systemic thromboembolism, with reduction in intracranial haemorrhage rates. Struggling efforts were made so that NOACs could enter in the therapeutic arsenal of patients with thromboembolic risk, the relative high cost being a limiting factor for their widespread use. The therapy with these drugs is implemented in daily practice based on the recommendation of the current guidelines, results of the randomised controlled trials (RCTs) and "real-world data" extracted from several important registries [19]. One of the main advantages of NOACs is a simplified therapy with fixed doses and no need for coagulation monitoring [23]. Choosing the right NOACs for each patient remains one of the most challenging problems of current clinical practice for a physician. NOACs have captured the interest of physicians since their emergence [24].

The aim of the study was to analyse the prescription of oral anticoagulant therapy, especially NOACs, in patients with atrial fibrillation and heart failure. The study aimed to evaluate whether there are differences and/or similarities between patients with permanent atrial fibrillation and chronic heart failure, who have been prescribed NOACs or VKA for the prevention of thromboembolic events.

\section{Materials and Methods}

\section{Study population}

We conducted an observational, descriptive, retrospective study among adult patients who have been discharged from the Emergency County Clinical Hospital of Oradea, Romania with the diagnosis of permanent $\mathrm{AF}$ and chronic $\mathrm{HF}$. We evaluated a total of 718 patients consecutively discharged from the Cardiology Clinic of the Emergency County Clinical Hospital of Oradea, Romania, from January 2014 to December 2017. The main inclusion criteria in the study was the concomitant diagnosis with permanent $\mathrm{AF}$ and chronic HF (with reduced or preserved ejection fraction).

Since all the patients enrolled in the study had permanent $\mathrm{AF}$ and chronic $\mathrm{HF}$, they achieved at least 1 point in the $\mathrm{CHA}_{2} \mathrm{DS}_{2}$-VASc score (clinical prediction score for estimating the risk of stroke in patients with atrial fibrillation) [10]; thus, according to the current European Society of Cardiology guidelines, all of them had an indication for anticoagulant treatment.

We divided the patients into two groups, depending on their anticoagulation therapy (used for prevention of thromboembolic events). The first group included patients who were using VKA (acenocoumarol) and the second group included patients under treatment with NOACs.

\section{Evaluation, data acquisition}

The data were obtained from the patient's medical records; the clinical relevant information, as well as their treatment (during hospitalization and at discharge), were recorded. The international normalised ratio (INR) is a standardized laboratory test used to assess the anticoagulant efficacy of VKA.

$\mathrm{AF}$ and $\mathrm{HF}$ were diagnosed and classified as defined by the European Society of Cardiology (ESC) and the European Heart Rhythm Association. Arterial hypertension was defined based on clinical history or the use of anti-hypertensive medication at admission. Diabetes mellitus was diagnosed if the serum glucose level was greater than $126 \mathrm{mg} / \mathrm{dL}$ (at two measurements), the value of glycosylated haemoglobin (HbA1c) was greater than $6.5 \%$, or the patients used oral antidiabetic agents or insulin. The diagnosis of chronic kidney disease was determined by a creatinine clearance (calculated by the modification of diet in renal disease (MDRD) formula) of less than $60 \mathrm{~mL} / \mathrm{min} / 1.73 \mathrm{~m}^{2}$. Ischemic or haemorrhagic stroke was certified by cerebral computed tomography (performed during hospitalization or in the emergency department) and neurological evaluations. Patients who met the inclusion criteria, but died within the specified observation interval, were also included in the study.

The current research has been conducted in accordance with the ethical principles set out by the Helsinki Declaration and Good Clinical Practice Recommendations and was approved by the hospital's Ethics Committee.

Statistical methodology of the data

All statistical analyses were performed using a statistical analysis software. Results are presented as mean \pm standard deviation (SD) (for numeric variables) or percentages. Continuous normal distribution variables were reported as mean and SD. The categorical variables were reported as percentages. Continuous variables were analysed for normalization and compared using the Student $t$ 
FARMACIA, 2018, Vol. 66, 6

test; they were expressed by mean and standard and/ or median deviation. The correlation degrees (r) between the studied parameters were evaluated by calculating the Pearson correlation coefficient. A $\mathrm{p}<0.05$ limit value was considered statistically significant. Intergroup comparisons were performed using either the Chi-square test or the one-way ANOVA method, to evaluate to what extent the differences between the independent and dependent variables are statistically significant. Later, we tested the assumptions (controlling the independent variables) using the multinomial logistic regression method, to identify the direct effects and potential mistaken effects.

\section{Results and Discussion}

During the 4 years of the study, 718 patients with AF and HF were included, of whom 463 patients used VKA (acenocoumarol) and 255 patients received anticoagulation treatment with NOACs. In the NOACs group, 104 patients received dabigatran, 102 patients' apixaban and 49 patients' rivaroxaban, as seen in Figure 1.

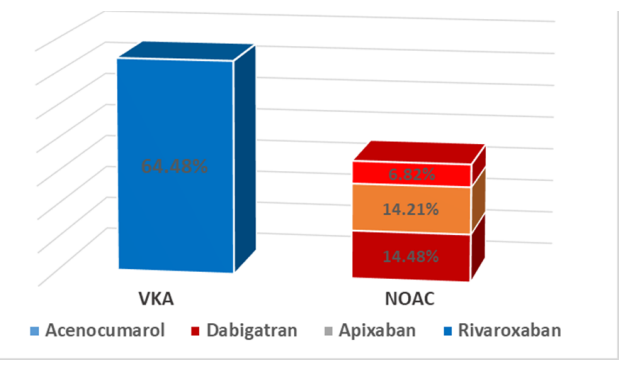

Figure 1.

Patients' anticoagulation treatment
In the first group, the mean age was $73.12 \pm 10.867$ years, compared to the NOACs group, where the mean age was $71.63 \pm 11.278$ years. In the first group, no significant sex related - differences could be noted compared to the second group, in which we observed a slight male predominance $(56.86 \%)$.

INR values were measured for patients in the first group. Only $39.95 \%$ had an INR within the recommended range, most patients $(60.05 \%)$ failing to maintain the INR within the therapeutic target (INR 2-3). This is most probably due to the fact that the values of the INR may be influenced by many factors (drugs, certain food, and medical conditions), requiring frequent dosage adjustments and close monitoring.

In the second group of patients, treated with NOACs, we noticed a slight preference in prescribing dabigatran (40.78\%) and apixaban $(40.00 \%)$, compared to rivaroxaban (19.22\%). Dabigatran is the first NOAC introduced in Romania and the high percentage of patients using it, in the present study, is possibly due to the physicians' confidence and experience with this drug. Apixaban, the latest NOAC introduced in Romania, has also recorded a higher percentage compared to rivaroxaban.

In addition to anticoagulant treatment, patients received treatment for the underlying disease. The most prescribed medications were: diuretics, gastric protectors, acetylsalicylic acid, beta-blockers, iron supplements, angiotensin converting enzyme inhibitors (ACEI), statins, digoxin and other antiplatelet agents (clopidogrel, prasugrel, ticagrelor). In Table I, the prescribed medication at discharge is listed.

Table I

Medication prescribed at discharge in the two groups

\begin{tabular}{|c|c|c|c|}
\hline Medication prescribed & VKA $(\mathrm{n}=)$ & NOACs $(\mathrm{n}=)$ & $\mathrm{p}$ \\
\hline ACEI & 210 & 116 & 0.001 \\
\hline ARB & 129 & 59 & 0.098 \\
\hline Diuretic & 427 & 160 & 0.000 \\
\hline Beta blockers & 252 & 125 & 0.095 \\
\hline Digoxin & 239 & 51 & 0.000 \\
\hline Statins & 242 & 132 & 0.017 \\
\hline Calcium channel blocking agents & 126 & 52 & 0.026 \\
\hline \multicolumn{1}{|c|}{ dihydropyridines } & 15 & 2 & 0.001 \\
\hline Acetylsalicylic acid & 95 & 95 & 0.000 \\
\hline Protons pump inhibitors & 308 & 102 & 0.000 \\
\hline Flecainide & 1 & 14 & 0.000 \\
\hline Amiodarone & 139 & 89 & 0.104 \\
\hline Trimetazidine & 65 & 29 & 0.185 \\
\hline Anxiolytics & 29 & 36 & 0.000 \\
\hline Iron supplements & 14 & 22 & 0.001 \\
\hline Theophylline & 110 & 28 & 0.000 \\
\hline Other antiplatelets & 37 & 57 & 0.000 \\
\hline Hepatoprotectors & 29 & 7 & 0.026 \\
\hline Central $\alpha$-blockers & 40 & 7 & 0.001 \\
\hline Vasodilators & 74 & 16 & 0.000 \\
\hline
\end{tabular}

VKA: vitamin K antagonists; NOACs: non vitamin K oral anticoagulants; ACEI: angiotensin converting enzyme inhibitors; ARB: angiotensin II receptor blockers. 
For the group using VKA, the most prescribed drugs were: diuretics, proton pump inhibitors, statins, digoxin and ACEI. As expected, the most common drugs prescribed with NOACs were: diuretics, statins, beta-blockers, ACEI and proton pump inhibitors. Patients treated with VKA received more frequently treatment with proton pump inhibitors than those treated with NOACs, this reflecting most probably the prescribing physicians' fear of gastrointestinal bleeding in patients treated with VKA.

The current study explored the real life oral anticoagulant treatment in a targeted group population, in a clinic from the North-Western region of Romania. The population group included subjects from all age groups, equally distributed according to gender.

The association of AF and $\mathrm{HF}$ is a topic that has raised the interest of researchers and medical community over the time, AF being common in patients with HF. The complex profile of patients who present both pathologies is of particular interest [24, 25]. To our knowledge, although an important subject, there has not been any study to evaluate the in-hospital and out of hospital treatment in this specific group population, in a representative population group from Romania.

The epidemiological similarities between AF and $\mathrm{HF}$ are explained, at least in part, by shared risk factors, such as high blood pressure, diabetes mellitus, chronic kidney disease, ischemic heart disease and valvular disease [14]. Pathogenic mechanisms in $\mathrm{AF}$ and $\mathrm{HF}$ include neuro-hormonal alterations, oxidative stress, fibrosis, and maladaptive hemodynamic and pressure-related changes [1].

The data from the current study regarding sexrelated differences and age are similar with those found in the literature [17].

As stated in the European registries [3], there is a high variability across European regions regarding the prescription of NOACs, clearly outlining the implementation gap of current guidelines recommendations, which prefer NOACs over VKA $[9,22]$. In an earlier analysis of the European AF registry, patients from the Southeast Europe were less likely to be treated in accordance with the guidelines [2,7].

In our study, the most prescribed NOACs in patients with $\mathrm{AF}$ and chronic $\mathrm{HF}$ were dabigatran (the first NOAC released in our country) and apixaban (the last released). Our findings are somewhat in contradiction with other important studies [5,13], that have found dabigatran [5] and rivaroxaban [2] as the most prescribed NOACs.

The new therapeutic perspectives in anticoagulant treatment reveal new opportunities, broaden the therapeutic horizon, thus increasing the life expectancy and improving the quality of life of these patients. The thrombo-prophylaxis with AVK in patients with AF is limited by the suboptimal control of INR. As recommended by the current guidelines [9], both groups of patients in our study received treatment of their underlying disease.

\section{Study limitations}

The limits of the study derive from its retrospective nature. The study was not designed to assess the efficacy and safety of NOACs versus AVK in patients with AF and HF, but to offer some insights from the clinical practice about the current trend regarding the anticoagulant treatment in Romania.

\section{Conclusions}

An important percentage of patients with AF and HF, under treatment with VKA, were not optimally controlled (INR outside the therapeutic range), being at risk both for thromboembolic and haemorrhagic events. It is important to be aware of the fact that the association of HF in patients with AF may increase the likelihood of an inadequate anticoagulation when using AVK, with suboptimal time in the therapeutic range. NOACs are challenging the traditional anticoagulant agents in a large majority of patients, due to their efficacy, fixed dosing regimens, more stable therapeutic window, and decreased risk of bleedings [19].

The integrated approach should be the cornerstone in the management of patients with permanent AF and HF. Anticoagulant therapy should be centred towards individual patient rather than general population. In the future, there is a possibility that NOACs will dramatically change the way patients with AF and HF are treated.

\section{Conflicts of interest}

The authors declare no conflict of interest.

\section{References}

1. Antonescu A, Mureşan M, Micle O, Micle L, Vicaş L, Dorofteiu M, Serum oxidative stress parameters and homocysteine levels in patients with renal transplant. Farmacia, 2008; LVI(3): 652-356.

2. Bordignon $\mathrm{S}$, Corti $\mathrm{MC}$, Claudio Bilato $\mathrm{C}$, Atrial fibrillation associated with heart failure, stroke and mortality. Journal of Atrial Fibrillation, 2012; 5(1): 1-9.

3. Boriani G, Proietti M, Laroche C, Fauchier L, Marin F, Nabauer M, Potpara T, Dan GA, Kalarus Z, Diemberger I, Tavazzi L, Maggioni AP, Lip GY, Contemporary stroke prevention strategies in 11096 European patients with atrial fibrillation: a report from the EURObservational Research Programme on Atrial Fibrillation (EORP-AF) LongTerm General Registry. EP Europace, 2018; 20(5): 747-757. 
FARMACIA, 2018, Vol. 66, 6

4. Colilla S, Crow A, Petkun W, Singer DE, Simon T, Liu X, Estimates of current and future incidence and prevalence of atrial fibrillation in the U.S. adult population. Am J Cardiol., 2013; 112(8):1142-1147.

5. Connolly SJ, Ezekowitz MD, Yusuf S, Eikelboom J, Oldgren J, Parekh A, Pogue J, Reilly PA, Themeles E, Varrone J, Wang S, Alings M, Xavier D, Zhu J, Diaz R, Lewis BS, Darius H, Diener HC, Joyner CD, Wallentin L; RE-LY Steering Committee and Investigators, Dabigatran versus warfarin in patients with atrial fibrillation. $N$ Engl J Med., 2009; 361(12): 1139-1151.

6. Garcia D, Libby E, Crowther M, The new oral anticoagulants. Blood, 2010; 115(1): 15-20.

7. Go AS, Hylek EM, Phillips KA, Chang Y, Henault LE, Selby JV, Singer DE, Prevalence of diagnosed atrial fibrillation in adults: national implications for rhythm management and strok eprevention: the AnTicoagulation and Risk Factors in Atrial Fibrillation (ATRIA) Study. JAMA, 2001; 285(18): 2370-2375.

8. Gong, Kim RB, Importance of pharmacokinetic profile and variability as determinants of dose and response to dabigatran, rivaroxaban, and apixaban. Can J Cardiol., 2013; 29(7 Suppl): S24-S33.

9. Kirchhof P, Benussi S, Kotecha D, Ahlsson A, Atar D, Casadei B, Castella M, Diener HC, Heidbuchel H, Hendriks J, Hindricks G, Manolis AS, Oldgren J, Popescu BA, Schotten U, Van Putte B, Vardas P; ESC Scientific Document Group, 2016 ESC Guidelines for the management of atrial fibrillation developed in collaboration with EACTS. European Heart Journal, 2016; 37(38): 2893-2962.

10. Kotecha D, Piccini JP, Atrial fibrillation in heart failure: what should we do? Eur Heart J., 2015; 36(46): 3250-3257.

11. Larned JM, Laskar RS, Atrial fibrillation and heart failure. Congestive Heart Failure, 2009; 15(1): 24-30.

12. Lip GYH, Stroke prevention in atrial fibrillation: changing concepts. European Heart Journal Cardiovascular Pharmacotherapy, 2015; 1(2): 76-79.

13. Lopes RD, Alexander JH, Al-Khatib SM, Ansell J, Diaz R, Easton JD, Gersh BJ, Granger CB, Hanna M, Horowitz J, Hylek EM, McMurray JJ, Verheugt FW, Wallentin L; ARISTOTLE Investigators, Apixaban for reduction in stroke and other ThromboemboLic events in atrial fibrillation (ARISTOTLE) trial: design and rationale. Am Heart $J ., 2010 ; 159(3)$ : 331-339.

14. Maisel WH, Stevenson LW, Atrial fibrillation in heart failure: epidemiology, pathophysiology, and rationale for therapy. Am J Cardiol., 2003; 91(6A): 2D-8D.

15. Masotti L, Campanini M, Pharmacology of new oral anticoagulants: mechanism of action, pharmacokinetics, pharmacodynamics. It J Med., 2013; 7(s8): 1-7.

16. Mozaffarian D, Benjamin EJ, Go AS, Arnett DK, Blaha MJ, Cushman M, de Ferranti S, Després JP, Fullerton HJ, Howard VJ, Huffman MD, Judd SE, Kissela BM, Lackland DT, Lichtman JH, Lisabeth
LD, Liu S, Mackey RH, Matchar DB, McGuire DK, Mohler ER 3rd, Moy CS, Muntner P, Mussolino ME, Nasir K, Neumar RW, Nichol G, Palaniappan L, Pandey DK, Reeves MJ, Rodriguez CJ, Sorlie PD, Stein J, Towfighi A, Turan TN, Virani SS, Willey JZ, Woo D, Yeh RW, Turner MB; American Heart Association Statistics Committee and Stroke Statistics Subcommittee, Heart disease and stroke statistics - 2015 update: a report from the American Heart Association. Circulation, 2015; 131(4): e29-e322.

17. O'Neal WT, Sandesara P, Hammadah M, Venkatesh S, Samman-Tahhan A, Kelli HM, Soliman EZ, Gender differences in the risk of adverse outcomes in patients with atrial fibrillation and heart failure with preserved ejection fraction. Am J Cardiol., 2017; 119(11): 1785-1790.

18. Parepa IR, Suceveanu AI, Mazilu L, Mohamed A, Nita D, Tita LA, Preventing cardiac complications after non-cardiac non-vascular surgery by using perioperative statin therapy - a prospective study in Constanta County, Romania. Farmacia, 2017; 65(1): 120-124.

19. Pelliccia F, Tanzilli G, Schiariti M, Viceconte N, Greco C, Gaudio C, Real-world data on novel oral anticoagulants: the added value of registries and observational studies. G Ital Cardiol (Rome), 2016; 17(12 Suppl 3): 3S-21S.

20. Salem JE, Sabouret P, Funck-Brentano C, Hulot JS, Pharmacology and mechanisms of action of new oral anticoagulants. Fundamental \& Clinical Pharmacology, 2015; 29(1): 10-20.

21. Tamayo S, Frank Peacock W, Patel M, Sicignano N, Hopf KP, Fields LE, Sarich T, Wu S, Yannicelli $\mathrm{D}$, Yuan $\mathrm{Z}$, Characterizing major bleeding in patients with nonvalvular atrial fibrillation: a pharmacovigilance study of 27467 patients taking rivaroxaban. Clin Cardiol., 2015; 38(2): 63-68.

22. Taerel AE, Rosenberg L, Nicolescu T, Ethics and equity in providing pharmaceutical assistance to the population. Revista Romana de Bioetica, 2010; 8(1): 150-154.

23. Vrijens B, Heidbuchel $H$, Non-vitamin $K$ antagonist oral anticoagulants: considerations on once- $v s$. twice-daily regimens and their potential impact on medication adherence. Europace, 2015; 17(4): 514-523.

24. Xiong Q, Lau YC, Senoo K, Lane DA, Hong K, Lip GYH, Non-vitamin $\mathrm{K}$ antagonist oral anticoagulants (NOACs) in patients with concomitant atrial fibrillation and heart failure: a systemic review and meta-analysis of randomized trials. Eur J Heart Fail., 2015; 17(11): 1192-1200.

25. Zannad F, Ferreira JP, Oral anticoagulant agents in patients with atrial fibrillation and heart failure. JACC: Heart Failure, 2016; 4(11): 881-884.

26. Zhao L, Wang WYS, Xinchun Y, Anticoagulation in atrial fibrillation with heart failure. Heart Failure Reviews, 2018; 23(4): 563-571. 